\title{
Comprehensive Profiling of N-Linked Glycosylation Sites in HeLa Cells Using Hydrazide Enrichment
}

\author{
Helle Malerod, ${ }^{\dagger}$ Robert L. J. Graham, ${ }^{\ddagger}$ Michael J. Sweredoski, ${ }^{\ddagger}$ and Sonja Hess ${ }^{\ddagger} * *$ \\ ${ }^{\dagger}$ Department of Chemistry, University of Oslo, P.O. Box 1033 Blindern, 0315 Oslo, Norway \\ ${ }^{\ddagger}$ Proteome Exploration Laboratory, Beckman Institute, California Institute of Technology, Pasadena, California 91125, United States
}

Supporting Information

ABSTRACT: The adenocarcinoma cell line HeLa serves as a model system for cancer research in general and cervical cancer in particular. In this study, hydrazide enrichment in combination with state-of-the art nanoLC-MS/MS analysis was used to profile N-linked glycosites in HeLa cells. N-Linked glycoproteins were selectively enriched in HeLa cells by the hydrazide capture method, which isolates all glycoproteins independent of their glycans. Nonglycosylated proteins were removed by extensive washing. N-Linked glycoproteins were identified with the specific NXT/S motif and deamidated asparagine $(\mathrm{N})$. Deglycosylation was carried out in both $\mathrm{H}_{2}{ }^{16} \mathrm{O}$ and $\mathrm{H}_{2}{ }^{18} \mathrm{O}$ to confirm the deamidation. NanoLC-MS/MS analysis indicated that the method selectively enriched at least 100 fold $\mathrm{N}$-linked glycosites in HeLa cells. When both the membrane and cytosolic fractions were used, a total of 268 unique $\mathrm{N}$ glycosylation sites were identified corresponding to 106 glycoproteins. Bioinformatic analysis revealed that most of the glycoproteins identified are known to have an impact on cancer and have been proposed as biomarkers.

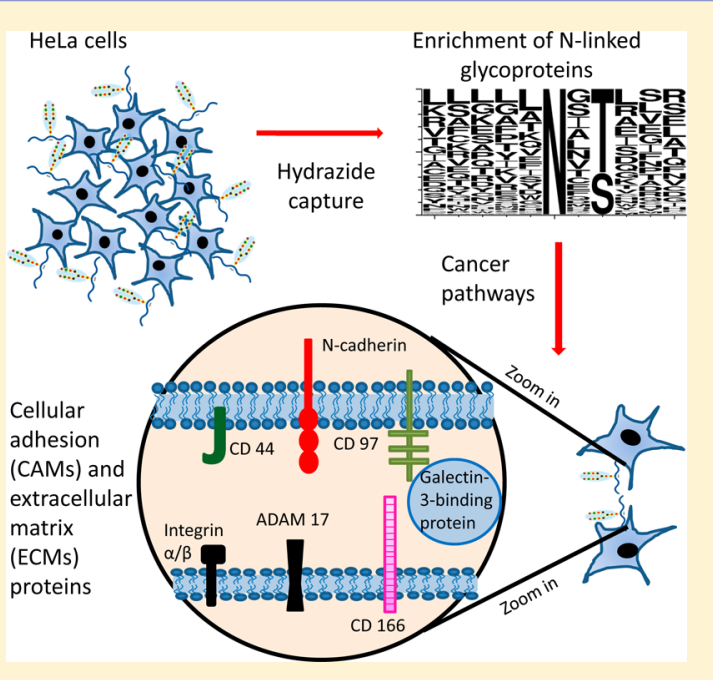

KEYWORDS: N-linked glycoproteins, hydrazide capture, HeLa cells, cancer, biomarkers

\section{INTRODUCTION}

Since its introduction as the first human cell line, HeLa has served as a model system for cancer research in general and cervical cancer in particular. In addition, research on HeLa cells was pivotal in our understanding of many biological processes. ${ }^{1}$ Originally, HeLa was derived from a cervical adenocarcinoma, caused by human papillomavirus. ${ }^{2}$ After breast cancer, cervical cancers represent the second most common cancer in women.

Current cancer treatment options include surgery, radiotherapy, chemotherapy, or combinations thereof. Biomarker research is needed for early detection, effective prevention, and treatment of cancer. It has, for instance, been shown that radiotherapy resistance can be diagnosed with biomarkers. ${ }^{3}$ However, the discovery of biomarkers is challenging and requires sensitive and selective methods that can determine low abundance proteins even in complex samples. Additionally, the sample amount and number of cells may also be limited making a selective sample preparation necessary in combination with state-of-the-art nanoLC-MS/MS. It has been recognized that the onset of tumors and metastases involve $\mathrm{N}$-glycosylated proteins. $^{4-6}$ In fact, glycoproteins are implicated in diverse biological functions that are essential for tumor development, growth, and metastases, including cell-matrix and cell-cell recognition, enzymatic activity, intracellular transport, protein folding, and regulation. ${ }^{7}$ Consequently, variations in glyco- proteins are associated with diseases and may therefore function as biomarkers of great clinical relevance. ${ }^{8,9}$

Glycoproteins can be categorized in mainly two groups: $\mathrm{N}$ linked and O-linked proteins. N-Linked glycoproteins, where the glycan is linked to asparagine $(\mathrm{N})$, are identified by the NXS/T motif where $\mathrm{X}$ can be any amino acid except proline (P). In the O-linked glycoproteins, the glycans are attached to either serine or threonine $(\mathrm{S} / \mathrm{T})$. Cell-surface or secreted glycoproteins, likely biomarkers, are predominantly $\mathrm{N}$-linked. ${ }^{10}$

There are different strategies to isolate and enrich glycoproteins, and the most commons are lectin based, ${ }^{11-15}$ boronate affinity chromatography, ${ }^{16-18}$ HILIC, ${ }^{19,20}$ and the hydrazide capture method. ${ }^{21-26}$ Lectins interact preferentially with certain glycans, and it is therefore necessary to use a combination of several lectins to isolate the majority of glycoproteins. Boronate affinity chromatography, HILIC, and the hydrazide capture method are universal methods and can isolate glycoproteins independent of the glycan structure. The hydrazide capture method has recently been applied to isolate both glycoproteins and glycopeptides in different cell lines and bacteria, ${ }^{27-31}$ saliva, $^{32}$ and rat myocardium ${ }^{33}$ and to explore the effect of oxidants on oxidative stress in plasma in diabetic rats. ${ }^{34}$

Received: July 18, 2012

Published: November 23, 2012 
Here, we use the hydrazide capture method to selectively enrich N-linked glycosites in HeLa cells. The method was applied for both membrane and cytosolic proteins. The $\mathrm{N}$ linked glycoproteins were identified by the characteristic NXS/ $\mathrm{T}$ motif and deamidated asparagine. More than 250 unique glycosylation sites were identified including novel glycosylation sites in known and novel glycoproteins. Interestingly, when compared to the membrane fraction more glycosylation sites were identified in the cytosol fraction. Lastly, most of the $\mathrm{N}$ linked glycoproteins identified are known to have an impact on cancer.

\section{EXPERIMENTAL SECTION}

\subsection{Chemicals and Reagents}

Dulbecco's modified Eagle's medium (DMEM) containing 10\% fetal bovine serum (FBS), 1\% L-glutamine, 1\% Pen/Strep, and PBS was purchased from Invitrogen (Carlsbad, CA). Water, acetonitrile (ACN) (Chromasolv LC-MS quality), trifluoroacetic acid (99+\%), formic acid (99\%), ammonium bicarbonate (ABC), DL-dithiothreitol (DTT), HEPES, iodoacetamide (IAM), octyl- $\beta$-D-1-glucopyranoside, sodium acetate $(\mathrm{NaOAc})$, sodium metaperiodate $\left(\mathrm{NaIO}_{4}\right)$, urea and triethylammonium bicarbonate were supplied by Sigma-Aldrich (St. Louis, MO). Methanol (MeOH) was from J.T. Baker by Avantor Performance Materials (Center Valley, PA).

Sodium chloride $(\mathrm{NaCl})$ was from Mallinckrodt Chemicals (Philipsburg, NJ) and Tris- $\mathrm{HCl}$ from MP Biomedicals, Inc. (Illkirch, France). $\mathrm{H}_{2}{ }^{18} \mathrm{O}$ (95-98 atom $\%{ }^{18} \mathrm{O}$ ) was from Isotech (Miamisburg, $\mathrm{OH}$ ). Sequencing-grade modified porcine trypsin was purchased from Promega Corp. (Madison, WI) and PNGase F and N-glycanase from Prozyme (Hayward, CA). Complete mini EDTA-free protease inhibitor was supplied by Roche Diagnostics GmbH (Mannheim, Germany). UltraLink hydrazide resins were supplied by Pierce, Thermo Scientific (San Jose, CA).

\subsection{Cell Culture and Oxidation}

HeLa cells were cultured in Dulbecco's modified Eagle's medium (DMEM) containing 10\% fetal bovine serum (FBS), $1 \%$ L-glutamine, $1 \%$ Pen/Strep, and 2.5\% HEPES. Cells were grown to $70 \%$ confluency in T-150 flasks (Becton Dickinson Labware, Franklin Lakes, NJ) before the media was removed and the cells $((55-80) \times 10 \mathrm{E} 6)$ were washed with $1 \times \mathrm{PBS}$ three times. The cells were harvested by centrifugation (1200 g, $5 \mathrm{~min}, 4^{\circ} \mathrm{C}$ ) and subsequently oxidized with $10 \mathrm{mM}$ sodium metaperiodate for $1 \mathrm{~h}$ in the dark at room temperature with gentle end-over-end mixing. A mixture of $100 \mathrm{mM}$ sodium acetate and $150 \mathrm{mM}$ sodium chloride ( $\mathrm{pH} 5.5)$ was used as oxidation buffer. The cell pellet was washed three times with 10 $\mathrm{mL} 1 \times \mathrm{PBS}$ to remove excess $\mathrm{NaIO}_{4}$.

\subsection{Cell Lysis and Membrane Preparation}

The cell pellet was resuspended in $2 \mathrm{~mL}$ of lysis buffer ( $1 \%$ solution (20 mM Tris- $\mathrm{HCl}, 150 \mathrm{mM} \mathrm{NaCl}, \mathrm{pH} 7.5), 20 \mathrm{mg}$ of the nonionic detergent octyl- $\beta$-D-1-glucopyranoside, and one tablet of complete mini EDTA-free protease inhibitor. Cells were homogenized using an ultrasound probe on ice and subsequently centrifuged at $38000 \mathrm{~g}, 1.5 \mathrm{~h}, 4{ }^{\circ} \mathrm{C}$ (Optima L-90K Ultracentrifuge, Beckman Coulter, Inc., Brea, CA) to isolate the membrane proteins. Prior to the hydrazide capture, the membrane pellet was redissolved in $600 \mu \mathrm{L}$ of a mixture of $1 \%$ solution ( $150 \mathrm{mM} \mathrm{NaCl}, \mathrm{pH} 7.5$ ), $20 \mathrm{mg}$ of the nonionic detergent octyl- $\beta$-D-1-glucopyranoside, and one tablet of complete mini EDTA-free protease inhibitor. An ultrasound probe was used to dissolve the membrane pellet completely. Cytosolic proteins were stored at $-20{ }^{\circ} \mathrm{C}$ and thawed prior to hydrazide capture.

\subsection{Hydrazide Capture of Membrane Proteins}

Oxidized membrane proteins $(600 \mu \mathrm{L})$ were mixed with $2.4 \mathrm{~mL}$ of hydrazide resins $\left(1_{\text {protein }} / 4_{\text {hydrazide }}\right.$ ratio, $\left.v / v\right)$ and incubated at room temperature for $40 \mathrm{~h}$ with end-over-end mixing. The hydrazide resins were washed twice with $50 \mathrm{mM} \mathrm{ABC}$ prior to the mixing. Proteins not retained on the resins were removed by centrifugation $(500 \mathrm{~g}, 5 \mathrm{~min})$ and subsequently washed three times with an equal volume of $8 \mathrm{M}$ urea and $100 \mathrm{mM} \mathrm{ABC}, \mathrm{pH}$ 8.4 and processed as described in the Supporting Information. The hydrazide resins were transferred to a $30 \mathrm{~K}$ Amicon Ultra centrifugal filter (15 mL, Millipore, Billercia, MA). Deionized water $(1.5 \mathrm{~mL})$ was added to the resins to increase the volume. The proteins were reduced with $50 \mathrm{mM}$ DTT incubated for $1 \mathrm{~h}$ and alkylated with $500 \mathrm{mM}$ iodoacetamide IAM for $30 \mathrm{~min}$. Both reduction and alkylation were carried out with gentle endover-end mixing at room temperature in the dark. The filter was centrifuged to remove the excess of DTT and IAM and washed three times with $150 \mathrm{mM} \mathrm{NaCl}$ and $50 \mathrm{mM} \mathrm{ABC}$, respectively. Proteins were dissolved in $1 \mathrm{~mL}$ of $50 \mathrm{mM} \mathrm{ABC}$ and digested overnight at room temperature using $20 \mu \mathrm{g}$ of sequencing grade modified porcine trypsin. Nonglycosylated peptides were recovered by centrifugation (nonglycopeptide). The hydrazide resins were subsequently washed with $2 \times 1 \mathrm{~mL}$ of $1.5 \mathrm{M} \mathrm{NaCl}$, $2 \times 1 \mathrm{~mL}$ of ACN/0.1\% TFA (80/20, v/v), $2 \times 1 \mathrm{~mL}$ of $\mathrm{MeOH}, 2 \times 1 \mathrm{~mL}$ of water, and $2 \times 1 \mathrm{~mL}$ of $8 \mathrm{M}$ urea/ $100 \mathrm{mM}$ $\mathrm{ABC}(\mathrm{pH}$ 8.4). The resulting 10 wash fractions were combined prior to the sample cleanup. The nonglycopeptide and wash fractions were analyzed by LC-MS/MS and combined in the subsequent analysis. A set of control samples was prepared by the same procedure except oxidation with $\mathrm{NaIO}_{4}$ was eliminated.

\subsection{Hydrazide Capture of Cytosolic Proteins}

The cytosolic proteins were oxidized by adding $10 \mathrm{mM} \mathrm{NaIO}_{4}$ in $0.5 \mathrm{~mL}$ of oxidation buffer $(100 \mathrm{mM} \mathrm{NaAc}$ and $150 \mathrm{mM}$ $\mathrm{NaCl}, \mathrm{pH} 5.5$ ) and incubated for $1 \mathrm{~h}$ at room temperature with end-over-end rotation. The sample was transferred to a $3 \mathrm{~K}$ Amicon centrifugational filter $(0.5 \mathrm{~mL}$, Millipore) and washed with $0.5 \mathrm{~mL}$ of PBS three times to remove excess $\mathrm{NaIO}_{4}$. A 100 $\mu \mathrm{L}$ portion of a mixture of $1 \%$ solution $(150 \mathrm{mM} \mathrm{NaCl}, \mathrm{pH}$ $7.5), 20 \mathrm{mg}$ of octyl- $\beta$-D-1-glucopyranoside, and one tablet of complete mini EDTA-free protease inhibitor were added to the proteins. A $400 \mu \mathrm{L}$ portion of $\mathrm{ABC}$ prewashed hydrazide resins $\left(1_{\text {protein }} / 4_{\text {hydrazide }}\right.$ ratio, v/v) was added, and the sample was conjugated to the resins at room temperature with end-overend mixing overnight. The hydrazide resins were transferred to an Eppendorf tube and centrifuged and washed three times with $8 \mathrm{M}$ urea in $100 \mathrm{mM} \mathrm{ABC}(\mathrm{pH} \mathrm{8.4)}$ to recover the proteins not bound to the resin (flow-through and wash).

Hydrazide resins were transferred to a $30 \mathrm{~K}$ Amicon centrifugational filter, and $400 \mu \mathrm{L}$ of $\mathrm{H}_{2} \mathrm{O}$ was added to increase the total volume. The proteins were reduced with 50 mM DTT (incubated for $1 \mathrm{~h}$ ) and alkylated with $500 \mathrm{mM}$ IAM $(30 \mathrm{~min})$. The reduction and alkylation was carried out with gentle end-over-end mixing at room temperature in the dark. The access of DTT and IAM was removed by centrifugation, and the proteins were washed three times with $150 \mathrm{mM} \mathrm{NaCl}$ and $50 \mathrm{mM} \mathrm{ABC}$, respectively. The proteins were dissolved in $350 \mu \mathrm{L}$ of $50 \mathrm{mM} \mathrm{ABC}$ and digested overnight at room 
temperature using $20 \mu \mathrm{g}$ of sequencing grade modified porcine trypsin. The conditions for recovering the nonglycosylated peptides were the same as for membrane proteins described above. A set of control samples was prepared by the same procedure as described for the membrane proteins.

\subsection{Deglycosylation and Release of $\mathrm{N}$-Linked Glycopeptides}

The N-linked glycopeptides were released from the hydrazide resins by incubating $100 \mu \mathrm{L}$ of washed resins with $500 \mu \mathrm{L}$ of 50 $\mathrm{mM} \mathrm{ABC}$ and either $4 \mu \mathrm{L}$ of PNGase F or $2 \mu \mathrm{L}$ of $N$-glycanase overnight at $37{ }^{\circ} \mathrm{C}$. For deglycosylation in $\mathrm{H}_{2}{ }^{18} \mathrm{O}, 200 \mu \mathrm{L}$ of 50 $\mathrm{mM} \mathrm{ABC}$ and $100 \mu \mathrm{L}$ of hydrazide resins were evaporated to remove all traces of $\mathrm{H}_{2}{ }^{16} \mathrm{O}$. To the vial with dried $\mathrm{ABC}$ were added $75 \mu \mathrm{L}$ of $\mathrm{H}_{2}{ }^{18} \mathrm{O}$ and PNGase $\mathrm{F}$ or N-glycanase, not dried, and the mixture was mixed well before being transferred to the dried hydrazide resins and incubated at $37{ }^{\circ} \mathrm{C}$ overnight.

\subsection{Protein Digestion in Unenriched Samples}

Approximately $50 \mu \mathrm{L}$ of membrane proteins and cytosolic (without hydrazide capture) were lyophilized and redissolved in $50 \mu \mathrm{L}$ of $8 \mathrm{M}$ urea/100 mM Tris- $\mathrm{HCl}(\mathrm{pH} 8.5)$. The proteins were reduced and alkylated with $50 \mathrm{mM}$ DTT and $500 \mathrm{mM}$ IAM as described above. A $100 \mu \mathrm{L}$ portion of $100 \mathrm{mMTris}-\mathrm{HCl}$ $(\mathrm{pH} 8.5)$ was added to the reduced and alkylated samples to decrease the concentration of urea to $1.4 \mathrm{M}$. Sequencing grade modified porcine trypsin $(20 \mu \mathrm{g})$ was dissolved in $200 \mu \mathrm{L}$ of water and added to the samples. Protein digestion was carried out at room temperature overnight with end-over-end mixing. The enzymatic protein digestion was quenched by addition of $10 \mu \mathrm{L}$ of $50 \%$ formic acid.

\subsection{Sample Cleanup}

All samples were lyophilized and resuspended in $0.1 \%$ TFA. The samples were desalted using the Sep-Pak $3 \mathrm{~cm}^{3}$ (200 mg) tC18 cartridge (Waters Corporation, Milford, MA) and if needed in-house made StageTips (Empore High Performance Extraction disks (C18) 3 M Center, St. Paul, MN). ${ }^{35,36}$ The Sep-Pak $3 \mathrm{~cm}^{3}$ tC18 SPE was conditioned with $2 \times 1 \mathrm{~mL}$ of $\mathrm{MeOH}, 2 \times 1 \mathrm{~mL}$ of ACN/0.1\% TFA (80/20, v/v), and $3 \times 1$ $\mathrm{mL}$ of $0.1 \%$ TFA. The sample was loaded on the Sep-Pak in 1 $\mathrm{mL} 0.1 \%$ TFA and washed with $0.1 \%$ TFA. The peptides were eluted in $3 \times 0.5 \mathrm{~mL}$ of ACN/0.1\% TFA $(80 / 20, \mathrm{v} / \mathrm{v})$. The C18 StageTips were activated by $50 \mu \mathrm{L}$ of $\mathrm{MeOH}, 50 \mu \mathrm{L}$ of ACN $/ 0.1 \%$ TFA $(80 / 20, \mathrm{v} / \mathrm{v})$, and $2 \times 50 \mu \mathrm{L}$ of $0.1 \%$ TFA. The sample was subsequently loaded in $50 \mu \mathrm{L}$ of $0.1 \%$ TFA prior to washing with $0.1 \%$ TFA before the peptides were eluted with $3 \times 50 \mu \mathrm{L}$. The eluates were lyophilized and dissolved in $10 \mu \mathrm{L}$ of $0.2 \%$ formic acid.

\subsection{LC-MS/MS}

The nanoLC-MS/MS analyses were carried out on an LTQ Orbitrap (Thermo Fisher Scientific, Waltham, MA) with a nanospray interface coupled to an EASY-nLC pump (Proxeon, now Thermo Fisher Scientific). A $5 \mu \mathrm{L}$ sample was loaded on a self-packed $5 \mu \mathrm{m}$ Reprosil C18AQ (Dr. Maisch GmbH, Ammerbuch-Entringen, Germany) column $(75 \mu \mathrm{m} \times 150$ $\mathrm{mm})$. Mobile phase A consisted of ACN/FA/ $\mathrm{H}_{2} \mathrm{O}(2 / 0.2 / 98$, $\mathrm{v} / \mathrm{v} / \mathrm{v})$, and mobile phase B was ACN/FA/ $\mathrm{H}_{2} \mathrm{O}(80 / 20 / 0.2$, v/ $\mathrm{v} / \mathrm{v})$. A 59 min gradient was used to separate the peptides. The gradient started at $0 \%$ B and increased linearly up to $40 \%$ within $50 \mathrm{~min}$ and was kept at $40 \% \mathrm{~B}$ for $1 \mathrm{~min}$ before it was increased to $100 \% \mathrm{~B}$ in $8 \mathrm{~min}$. The flow rate was $350 \mathrm{~nL} / \mathrm{min}$. All samples were analyzed with one blank (water) in between.
The LTQ Orbitrap was operated in data-dependent mode with full scan MS performed in the Orbitrap and a dependent MS/MS in the LTQ. The ESI spray voltage was $+2.10 \mathrm{kV}$, and the capillary temperature was $200{ }^{\circ} \mathrm{C}$. All spectra were acquired in positive mode in the range between $\mathrm{m} / z 300$ and 1700 at a resolution of 100,000. Collision-induced dissociation (CID) was performed in the ion-trap (IT) with a $35 \%$ normalized collision energy at the default activation $Q$ of 0.250 and activation time of $30 \mathrm{~ms}$. Charge state screening and rejection were enabled, and only charge states of the precursor ion $\geq+2$ were accepted. The ten most intense peptide ions were isolated. Dynamic exclusion settings of 1 repeated count over $30 \mathrm{~s}$ and exclusion duration of $90 \mathrm{~s}$. Xcalibur 2.0.7 (Thermo Scientific) was used to control both the EASY n-LC and the Orbitrap MS/ MS.

\subsection{Data Analysis}

Mascot (v 2.2.06, Matrix Science, London, UK) was used for protein identification. Trypsin was chosen as the enzyme, and the number of missed cleavages was set to 2 . The peptide charge was set to $2+$ and $3+$, and the peptide tolerance and MS/MS tolerance were $10 \mathrm{ppm}$ and $0.5 \mathrm{Da}$, respectively. The IPI human database (v 3.54, 75429 entries) was searched along with a common contaminant database (262 entries). A decoy database constructed as described by Cox et al. ${ }^{37}$ was appended to the target database. Cysteine carbamidomethylation was set as fixed modification while methionine oxidation, deamidation (NQ), deamidation: $18 \mathrm{O}$ (NQ) and Asn $\rightarrow$ Asp (N) were used as dynamic modifications for all database searches. Scaffold (v3.00.08, Proteome Software Inc., Portland, OR, USA) and WebLogo $3.1^{38}$ were used to validate the data. Protein identifications were based on a minimum of two peptides with a peptide probability of $95 \%$ and protein probability of 99\%. The estimated protein and peptide false discovery rate was estimated by Scaffold to be less than $1 \%$ based on the decoy database search results. Peptide identifications were accepted if they could be established at greater than 95\% probability as specified by the Peptide Prophet algorithm. ${ }^{39}$ Protein identifications were accepted if they could be established at greater than $95 \%$ probability and contained at least two identified peptides. Protein probabilities were assigned by the Protein Prophet algorithm. ${ }^{40}$ Proteins that contained similar peptides and could not be differentiated based on MS/ MS analysis alone were grouped to satisfy the principles of parsimony.

To identify which putative glycoproteins had been previously annotated as glycoproteins, all human proteins with the keyword "Glycoprotein [KW-0325]" were retrieved from UniProt in December 2011. ${ }^{41}$ The IPI identifiers of the putative glycoproteins were mapped to UniProt identifiers using PICR, ${ }^{42}$ and in-house scripts were then used to identify which putative glycoproteins were also annotated as glycoproteins in UniProt using the PICR mapping. Additionally, inhouse scripts were used to determine if the putative glycosylation sites were previously annotated in UniProt with N-linked glycosylation sequence annotations. Transmembrane domains (TMDs) were predicted with the TMHMM2.0 algorithm (http://www.cbs.dtu.dk/services/TMHMM/). UniProt and David Bioinformatics Resources $6.7^{43}$ were used to evaluate the enrichment of $\mathrm{N}$-linked glycoproteins. Kyoto Encyclopedia of Genes and Genomes (KEGG) analysis were used evaluate the pathways of the detected glycoproteins. ${ }^{44}$ 


\section{RESULTS AND DISCUSSION}

The aim of this study was to selectively isolate and profile $\mathrm{N}$ linked glycosylation sites in HeLa cells using the hydrazide capture method. The workflow of the experiments conducted is shown in Figure 1. Vicinal diols of the sugar moieties of

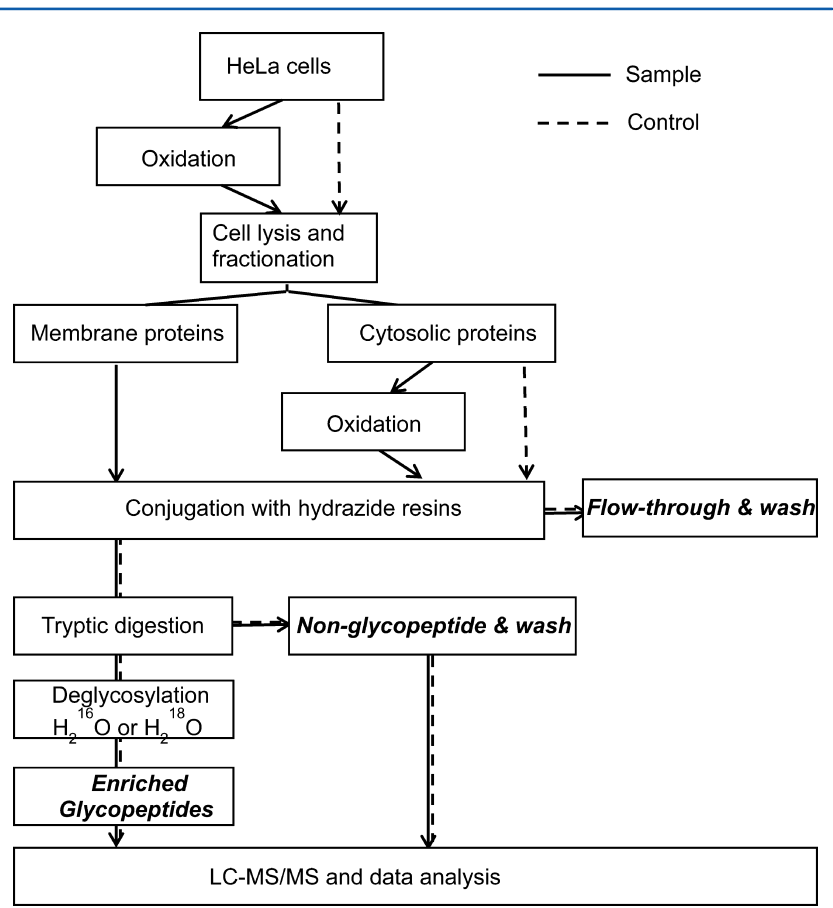

Figure 1. Workflow diagram of the hydrazide capture method of Nlinked glycoproteins in HeLa cells.

membrane proteins were selectively oxidized using sodium meta-periodate prior to cell lysis and isolation of membrane and cytosolic proteins by ultracentrifugation. In addition, the cytosolic fraction was oxidized after ultracentrifugation to capture potential glycosites in this fraction. Oxidized glycoproteins (and controls) were conjugated with hydrazide resins overnight, and subsequently centrifuged to remove those proteins that do not contain oxidizable sugar moieties (flowthrough and wash). The captured glycoproteins were trypsin digested, while the sugar residues were still attached to the hydrazide resins, and thus only the nonglycosylated peptides of the glycoproteins were released and recovered by centrifugation and extensive washing. These fractions are referred to as nonglycopeptide and wash. Finally, the enriched tryptic Nlinked glycopeptides were recovered by enzymatic deglycosylation in $\mathrm{H}_{2}{ }^{16} \mathrm{O}$ or $\mathrm{H}_{2}{ }^{18} \mathrm{O}$ (enriched glycopeptides). Control samples were prepared in the same manner excluding oxidation by sodium meta-periodate to explore potential unspecific interactions between the hydrazide resins and the $\mathrm{HeLa}$ proteins. The controls were deglycosylated in $\mathrm{H}_{2}{ }^{16} \mathrm{O}$. In addition, a set of unenriched samples (membrane and cytosolic proteins) was included to determine the enrichment of $\mathrm{N}$ linked glycoproteins of the hydrazide method (workflow not included in Figure 1). Two sample replicates were prepared for the oxidized glycoproteins (membrane and cytosolic) and control samples, respectively.

\subsection{Identified Glycosylation Sites}

Overall, 268 unique glycosylation sites have been identified in this study; 245 of those were identified in the cytosol and 111 in the membrane. While 88 glycosylation sites were identified in both the cytosol and membrane fraction, the majority were found in the cytosolic fraction. Table 1 lists the number of sites,

Table 1. Identification of Unique Glycosylation Sites in HeLa Glycoproteins from Membrane and Cytosolic Fractions

\begin{tabular}{lc} 
& unique glycosylation sites \\
membrane fraction & 88 \\
known site of known glycoprotein & 18 \\
novel site of known glycoprotein & 5 \\
novel site of novel glycoprotein & \\
cytosolic fraction & 184 \\
known site of known glycoprotein & 9 \\
novel site of known glycoprotein & 52 \\
novel site of novel glycoprotein & \\
\hline
\end{tabular}

subdivided in known and novel glycosylation sites of known and novel glycoproteins. All sites are specified in Tables S1 and S2 and best matching spectra of the deglycosylated peptides are shown in Supplementary Data 3 (Supporting Information).

We compared our results to a recent report from $\mathrm{McDonald}$ et al. identifying a total of 127 unique N-linked glycosylation sites in membrane associated HeLa cells using a combination of hydrazide capture and lectin affinity. ${ }^{45}$ Our data set has identified more than twice as many unique glycosylation sites using just one technique, namely the hydrazide capture, but extending the analysis to the cytosol and not limiting it to the membrane fraction. The reason for this experimental design was as follows. First, it has been our experience that invariably all cell fractionation techniques remain crude methods from a proteomics perspective, enriching but never fully separating all cell compartments. Second, glycoproteins in the membrane fraction pellet may be harder to resolubilize and thus might be lost in a proteomics analysis. Finally, all proteins that are targeted to the membranes need to be synthesized in the ribosomes, transported to the endoplasmic reticulum where they are being glycosylated to be then transported to their final destination. One should therefore expect to identify these glycoproteins also in the cytosolic fractions.

\subsection{Glycosylation Site Motif}

To further characterize the captured glycosylated peptides, we determined the amino acid composition of the glycosylation motifs. The unique sequences of all peptides containing a deamidated $\mathrm{N}$ were submitted to WebLogo ${ }^{38}$ and the resulting sequence atlas is shown in Figure 2. In the membrane and cytosolic fraction, $75 \%$ and $70 \%$, respectively, showed the NXT motif and the remainder had an NXS motif. This is in agreement with previous reports. ${ }^{46}$

\subsection{Identified Glycoproteins}

Overall, 106 glycoproteins were identified in this study. In the membrane fraction 57 glycoproteins were identified with 111 $\mathrm{N}$-glycosylation sites, and in the cytosol fraction 95 glycoproteins were found with $245 \mathrm{~N}$-glycosylation sites (Tables S1 and S2, Supporting Information). Forty-six proteins were common to both fractions. More glycoproteins were identified in the cytosol fraction compared to the membrane fraction. This could be due to the conditions used for oxidation since a high concentration of sodium periodate $(>2.5 \mathrm{mM})$ can lead to increased cell death. ${ }^{23}$ In the controls of the membrane and cytosolic fraction, zero and two glycosylation sites were 


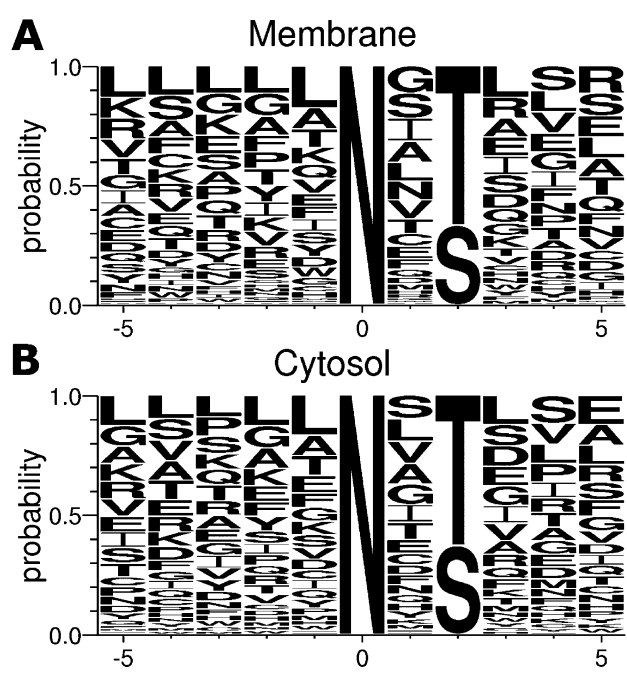

Figure 2. NXS/T motifs identified in the (A) membrane and (B) cytosolic fractions.

identified, respectively (Tables $S 1$ and S2, Supporting Information). The very low number of glycosylation sites in the controls indicated only minor unspecific interactions between unoxidized proteins and the resin. Overall, exceptional enrichment was observed when the enriched membrane fraction (111 glycosylation sites) was compared to an unenriched membrane sample (6 glycosylation sites) (Table S1, Supporting Information). The enrichment was even higher in the cytosolic fraction, where 245 glycosylation sites were identified in the enriched sample vs five in the unenriched samples (Table S2, Supporting Information).

For comprehensiveness, the membrane and cytosolic nonglycopeptide and wash fraction were also analyzed and contained 285 proteins and 316 proteins, respectively (Tables S3 and S4, Supporting Information). When filtered against UniProt for their known glycoproteins, 34 glycoproteins were identified in the membrane fraction and 106 glycoproteins were in the cytosolic fraction (Table S3 and S4, Supporting Information). The identification of these glycoproteins was primarily based on the presence of the nonglycosylated peptides.

\subsection{Novel Glycosylation Sites}

Among others, novel glycosylation sites have been identified for CD 276 antigen and mesothelin. CD 276 antigen has previously been identified in a global proteomics study focusing on the N-glycoproteome of human liver, ${ }^{47}$ where the N189 glycosylation site was detected in the peptide GYPEAEVFWQ-

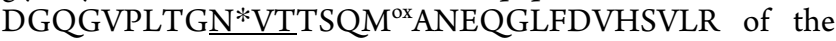
splice isoform 2. In a recent HeLa study, N104 and N215 were found to be glycosylated (LLAQGN*ASLRL and VVLGAN*GTYSC). ${ }^{45}$ Here, we report N104 and N215 and an additional site at N91 (GSAYAN*RTALF). Although it has long been known to be an $\mathrm{N}$-linked glycoprotein, so far no glycosylation sites were identified for mesothelin. ${ }^{48-50} \mathrm{We}$ identified all of the three potential glycosylation sites at N388 in DIRKWN*VTSLE, at N496 in AFQNMN*GSEYF, and N523 in ALSQQN*VSMDL. The MS/MS spectrum of the corresponding peptide ALSQQN*VSMDLATFMK is shown in Figure 3A. We also identified two glycosylation sites in the VDN*ITDQFCN*ASVVDPACVR peptide of Niemann-Pick C1 protein (Figure 3B). Both glycosylation sites of the Niemann-Pick $C 1$ protein are located in the cysteine rich luminal loop at N961 and N968. ${ }^{51,52}$

\subsection{Deglycosylation}

When using the hydrazide capture method it is necessary to enzymatically cleave the glycans of the peptides to recover the deglycosylated glycopeptides. During deglycosylation, asparagine (N) will be converted to aspartic acid (D), and the mass difference between a non- and deamidated glycopeptide will therefore correspond to the mass difference between asparagine and aspartic acid $(+0.98 \mathrm{Da})$. When the deglycosylation is performed in $\mathrm{H}_{2}{ }^{18} \mathrm{O}$, the mass difference between a non- and deamidated glycopeptide will increase to $+2.98 \mathrm{Da}$. In this study the deglycosylation was carried out in both $\mathrm{H}_{2}{ }^{16} \mathrm{O}$ and $\mathrm{H}_{2}{ }^{18} \mathrm{O}$. The mass differences of five representative $\mathrm{N}$-linked glycopeptides deglycosylated in $\mathrm{H}_{2}{ }^{16} \mathrm{O}$ and $\mathrm{H}_{2}{ }^{18} \mathrm{O}$ are shown in Table 2. As seen from Table 2, the differences correspond to

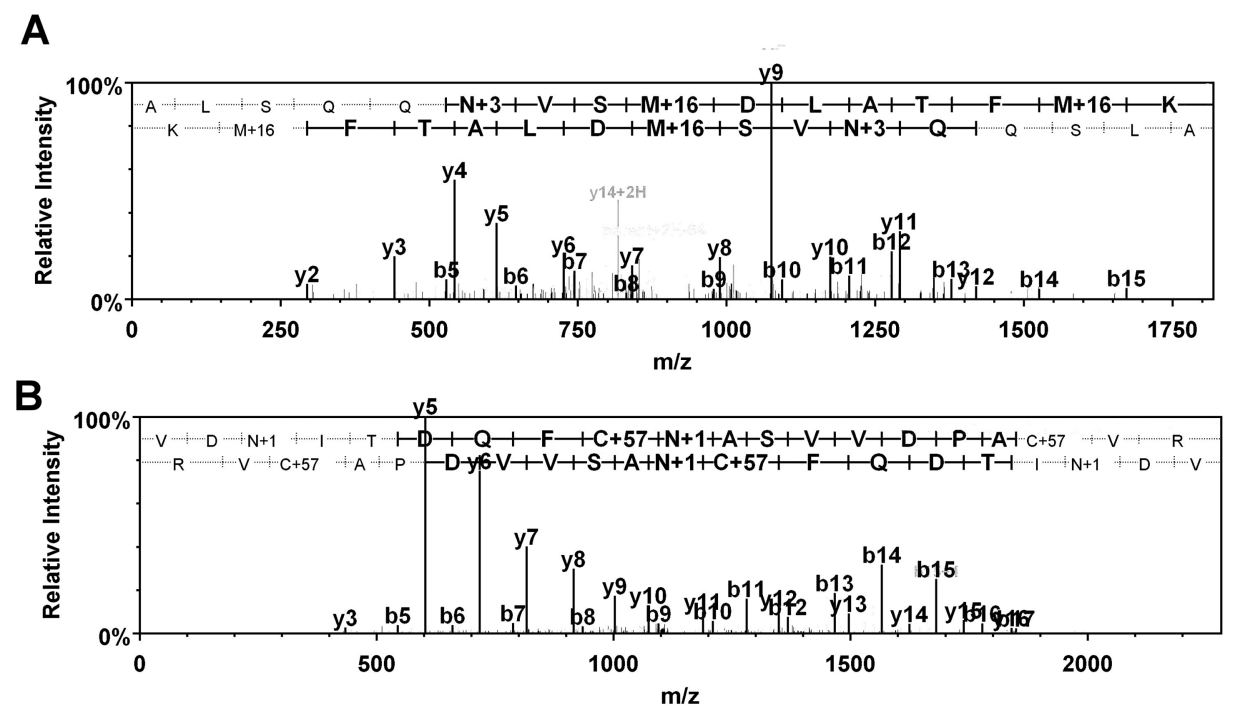

Figure 3. (A) MS/MS spectrum of novel glycosylation site (\#523) identified in peptide ALSQQN*VSMDLATFMK of mesothelin using ${ }^{18} \mathrm{O}-\mathrm{H}_{2} \mathrm{O}$ resulting in a mass shift of $3 \mathrm{Da}$. (B) MS/MS spectrum of novel glycosylation sites (\#961 and \#968) identified in peptide VDN*ITDQFCN*ASVVDPACVR of Niemann-Pick C1 protein (* indicates glycosylation site). 
Table 2. Mass Difference of Five Representative N-Linked Glycopeptides Identified in HeLa Cells Deglycosylated in $\mathrm{H}_{2}{ }^{16} \mathrm{O}$ and $\mathrm{H}_{2}{ }^{18} \mathrm{O}$, Respectively

\begin{tabular}{|c|c|c|c|c|c|c|}
\hline \multirow[b]{2}{*}{ peptide $^{a}$} & \multirow[b]{2}{*}{ mass without deglycosylation } & \multirow[b]{2}{*}{ protein } & \multicolumn{2}{|c|}{$\begin{array}{c}\text { deglycosylation in } \\
\mathrm{H}_{2}{ }^{16} \mathrm{O}\end{array}$} & \multicolumn{2}{|c|}{$\begin{array}{c}\text { deglycosylation in } \\
\mathrm{H}_{2}^{18} \mathrm{O}\end{array}$} \\
\hline & & & mass $(\mathrm{Da})$ & $\Delta(\mathrm{Da})$ & mass $(\mathrm{Da})$ & $\Delta(\mathrm{Da})$ \\
\hline (R)QTPEYQN*ESSR(N) & 1337.5848 & lysosomal acid phosphate & 1338.5622 & 0.9774 & 1340.5730 & 2.9882 \\
\hline (K)DFEDLYTPVN*GSIVIVR(A) & 1935.9941 & transferrin receptor protein 1 & 1936.9711 & 0.9770 & 1938.9825 & 2.9884 \\
\hline (K)AFN*STLPTMAQMEK(A) & 1567.7374 & CD44 antigen & 1568.7214 & 0.9840 & 1570.7257 & 2.9883 \\
\hline (R)TALFPDLLAQGN*ASLR(L) & 1685.9100 & CD276 antigen & 1686.8941 & 0.9841 & 1688.8983 & 2.9883 \\
\hline (R)RPPLAELAALN*LSGSRLDEVR(A) & 1663.9369 & trophoblast glycoprotein & 1664.9209 & 0.9840 & 1666.9252 & 2.9883 \\
\hline
\end{tabular}

the theoretical values and hence confirmed the peptides to be N-linked glycopeptides.

To investigate the effectiveness of the ${ }^{18} \mathrm{O}$-labeling procedure, we determined the percentage of deamidations that were found in the NXS/T motifs with a mass difference of $2.98 \mathrm{Da}$ versus $0.98 \mathrm{Da}$ in the enriched glycopeptides. More than $90 \%$ of the deamidated asparagines identified with a mass difference of $2.98 \mathrm{Da}$ had the NXS/T motif when the samples were deglycosylated in $\mathrm{H}_{2}{ }^{18} \mathrm{O}$ as shown in Figure 4 for proteins from the membrane and cytosolic fractions. Fewer than $10 \%$ were identified with a mass difference of $0.98 \mathrm{Da}$ and a
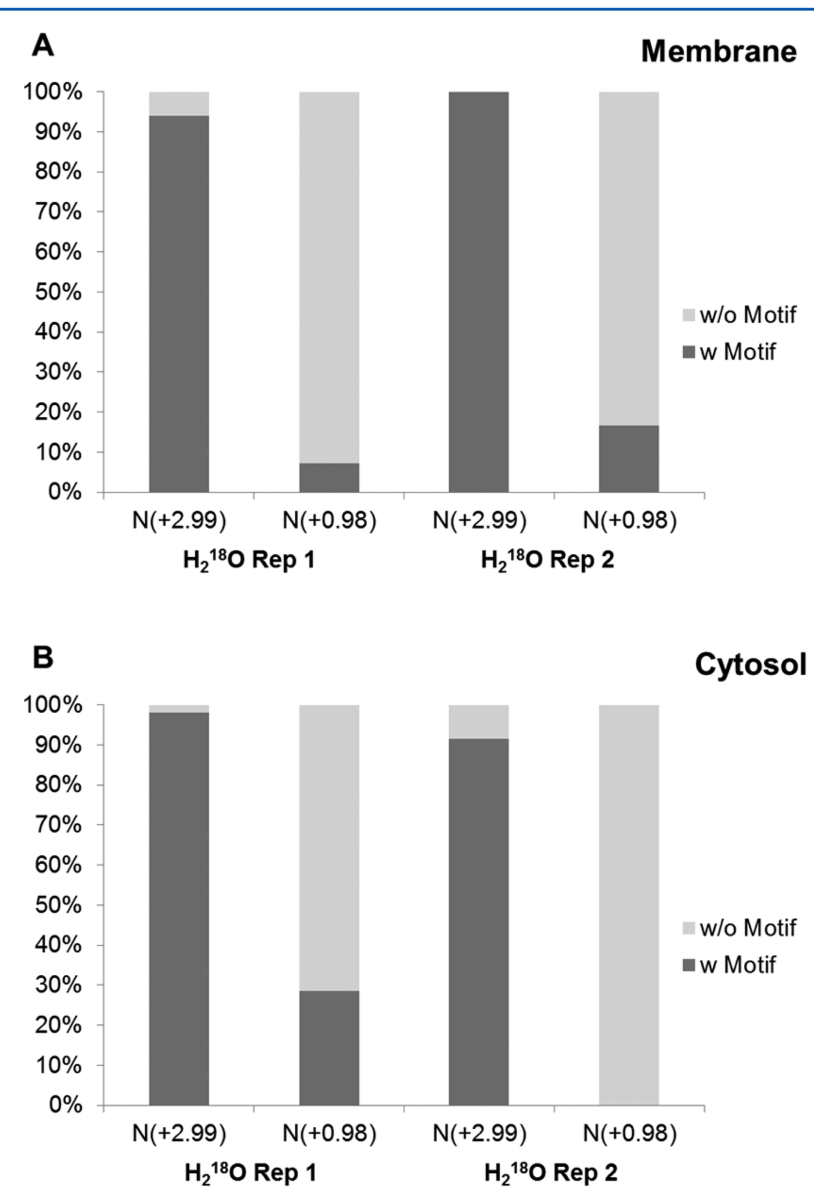

Figure 4. Percentage of deamidated asparagine $(\mathrm{N})$ identified with a mass difference of 2.98 and $0.98 \mathrm{Da}$ with (dark gray) and without (light gray) the NXS/T motif in (A) membrane and (B) cytosolic fractions after deglycosylation in $\mathrm{H}_{2}{ }^{18} \mathrm{O}$. Replicates (Rep) are shown separately. glycosylation motif, indicating a very high incorporation of $\mathrm{H}_{2}{ }^{18} \mathrm{O}$.

The reason for identification of glycosylation sites with only a $0.98 \mathrm{Da}$ mass difference may be due to not fully labeling, addition of PNGase $\mathrm{F}$ or N-glycanase that was not dried or back-exchange when dissolving the sample in $0.2 \%$ formic acid prior to nanoLC-MS/MS analysis. Finally, although unlikely, a small portion may also be due to spontaneous deamidation at proper glycosylation motifs.

An additional confirmation of $\mathrm{N}$-linked glycopeptides can also be obtained through MS/MS analysis. As an example, the MS/MS spectra of (R)TALFPDLLAQGN*ASLR(L) identified in isoform 1 of CD 276 antigen deglycosylated in $\mathrm{H}_{2}{ }^{16} \mathrm{O}$ and $\mathrm{H}_{2}{ }^{18} \mathrm{O}$ are shown in Supplementary data, Figure S1. All of the b- and $y$-ions corresponding to asparagine have a mass difference of $2 \mathrm{Da}$ between the $\mathrm{H}_{2}{ }^{16} \mathrm{O}$-deglycosylated and $\mathrm{H}_{2}{ }^{18} \mathrm{O}$-deglycosylated form of the peptide confirming successful deglycosylation and identification of $\mathrm{N}$-linked glycosylation sites.

\subsection{Enzymatic versus Chemical Deamidation}

As previously reported, asparagine can spontaneously deamidate to aspartic acid, even without the presence of deglycosylating enzymes. ${ }^{53,54}$ Therefore, additional measures are necessary to avoid false positive glycosylation site identification. ${ }^{18} \mathrm{O}$-labeling has previously been used successfully to further define the glycosylation sites. ${ }^{55}$ One might still argue that chemical deamidation might have happened in the presence of $\mathrm{H}_{2}{ }^{18} \mathrm{O}$ and thus is indistinguishable from an enzymatic deamidation.

To investigate this possibility, we determined the false discovery rate (FDR) of the glycosylation sites by comparing the number of deamidated $\mathrm{N}$ sites with $\mathrm{NXS} / \mathrm{T}$ motif vs random deamidation (without motif) between the enriched glycopeptide fractions of the oxidized (enriched) and unoxidized (control) samples collected. Since the unoxidized sample should not bind to the hydrazide resin, no enzymatic deglycosylation should occur in this sample.

As shown in Figure 5, we found zero deamidations in the membrane control samples and in the cytosol controls, two had an NXS/T motif (Tables S1 and S2, Supporting Information). This compares to a total of 199 and 349 redundant (resulting in 111 and 245 unique) NXS/T sites identified in the membrane and cytosol samples. From these data, we can estimate that our FDR for glycosylation site determination is less than $1 \%$, indicating a very low number of false glycosylation site identifications. 

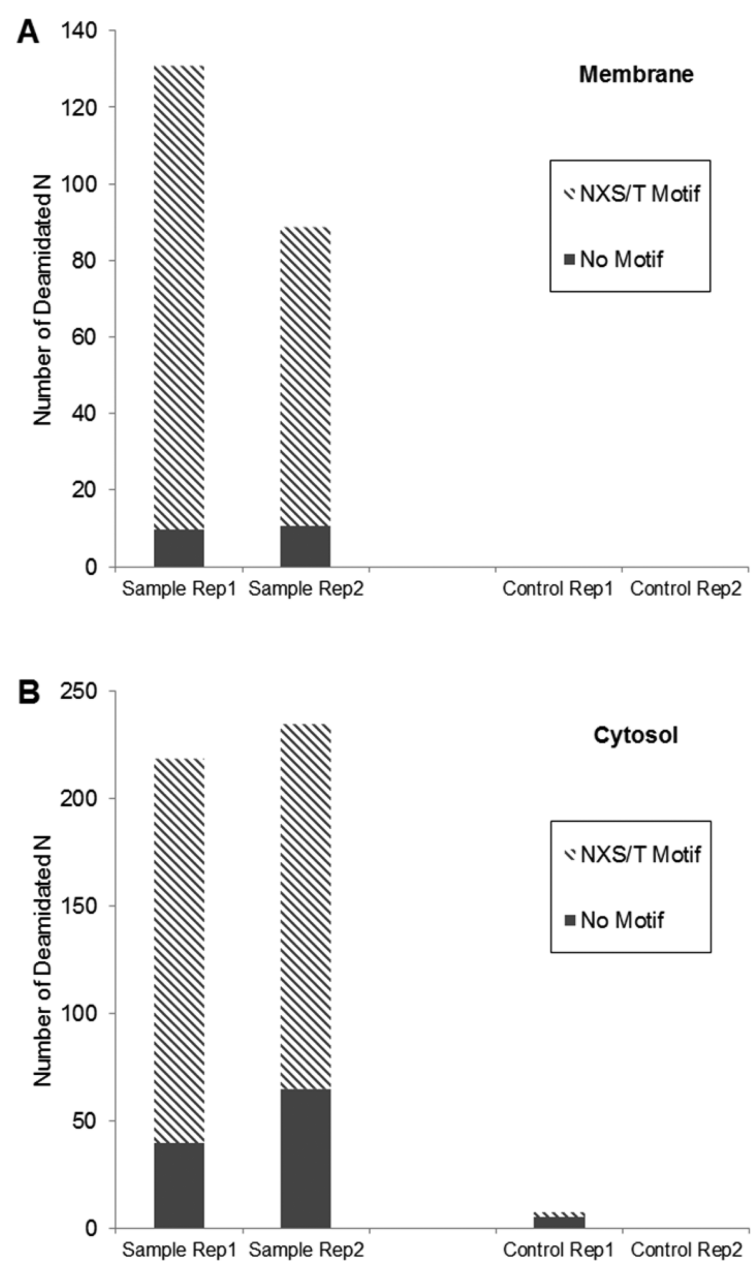

Figure 5. Number of deamidated asparagine $(N)$ identified with (striped pattern) and without (gray) the NXS/T motif in (A) membrane and (B) cytosolic fractions of the enriched glycopeptide samples and controls. Each replicate is shown separately. The FDR of false glycosylation site determinations was determined to be less than $1 \%$.

3.7. Enrichment of the N-Linked Glycosylation Sites in the Enriched Glycopeptide Fraction

To determine the enrichment of the hydrazide capture for glycosylated proteins, the percentage of the deamidated $\mathrm{N}$ with NXS/T glycosylation motif in the enriched glycopeptide fraction was compared to the unenriched sample as well as to known glycoproteins listed in UniProt. As shown in Figure 6, significant enrichment for glycosylation sites (Figure 6A) and glycoproteins (Figure 6B) was observed using the hydrazide capture method.

\subsection{Transmembrane Domain (TMD) Analysis}

To test whether the identified proteins from the membrane and cytosol fractions were indeed mostly transmembrane domain containing proteins, we separately analyzed the enriched proteins with identified glycosylation sites with TMHMM. As shown in Figure S2 (Supporting Information), the percentage of identified TM domains in membrane and cytosolic fraction is similar with ca. $50 \%$ containing $1 \mathrm{TMD}$, and the remainder containing up to 14 TMDs. In both cases, ca. $30 \%$ of the identified proteins were not predicted to contain a TMD. In addition, five proteins (bone marrow stromal antigen 2, cadherin-13, folate receptor 1, CD59 glycoprotein and
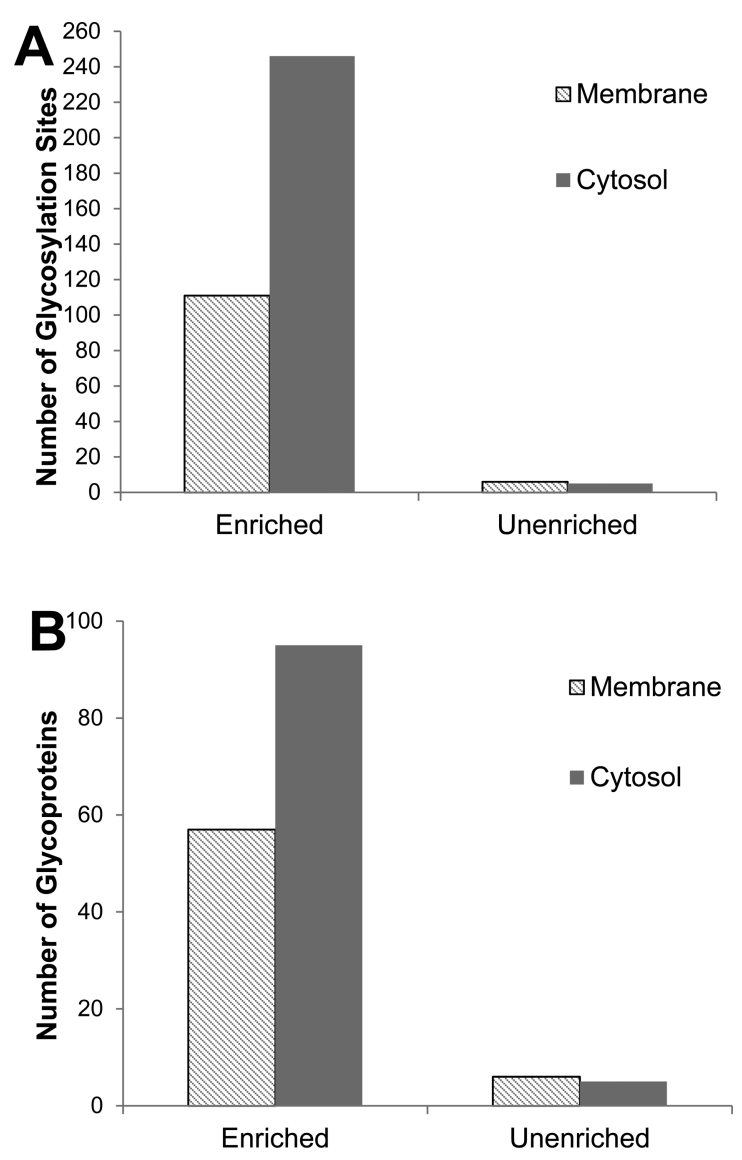

Figure 6. (A) Number of NXS/T motif containing glycosylation sites and (B) number of glycoproteins in enriched vs unenriched membrane (striped pattern) and cytosolic fractions (gray).

mesothelin) are predicted to have glycosylphospatidylinositol (GPI) anchors. ${ }^{56}$

\section{FUNCTIONAL ANALYSIS}

Glycoproteins identified in the enriched glycopeptides fraction were subjected to further bioinformatic analysis. While our experimental design enriched glycoproteins by at least 100 -fold, it was not meant to elucidate entire signaling cascades. Rather, it was designed to capture $\mathrm{N}$-linked glycoproteins, many of which are known to be involved in cancer-related signaling. DAVID analysis indicated a significant enrichment for the following cancer-related KEGG pathways: focal adhesion ( $p$ value $\left.2.91 \times 10^{-04}\right)$, cell adhesion molecules $(p$ value $5.49 \times$ $\left.10^{-05}\right), \mathrm{ECM}-$ receptor interaction ( $p$ value $\left.1.17 \times 10^{-07}\right)$, regulation of actin cytoskeleton ( $p$ value 0.023801012$)$, lysosome $\left(p\right.$ value $\left.1.95 \times 10^{-20}\right)$, small cell lung cancer $(p$ value $\left.8.20 \times 10^{-04}\right)$, pathways in cancer $(0.029302846)$, and sphingolipid metabolism ( $p$ value 0.014827196$)$. (Tables S7 and S8, Supporting Information).

\subsection{Cell Adhesion Molecules (CAMs) and Extracellular Matrix (ECM)-Receptor Interaction}

For a cancer cell to metastasize, it first needs to adhere to the extracellular matrix and surrounding stromal cells via cell adhesion molecules. Therefore, CAMs have been associated with tumor progression and metastasis and have been proposed as biomarkers. ${ }^{57-63}$ In general, they can be categorized into integrins, cadherins, and members of the immunoglobulin superfamily. 
Integrins are transmembrane glycoproteins that are involved in cell-matrix and cell-cell interactions. Integrins thus play a critical role in adhesion, cytoskeletal remodeling, and cell motility. Interestingly, integrin $\alpha-6$ (CD49f) has been identified as the primary receptor of human papillomavirus (HPV), known to have caused cancer in HeLa. ${ }^{2,64}$ In addition to integrin $\alpha-6$ mentioned above, cancer stem cell marker CD44, a heparan sulfate proteoglycan, may also be a receptor for human papillomavirus. ${ }^{65}$ When alternative splicing and glycosylation sites are taken into account, at least 20 variants of CD44 with different functions have been described so far. In fact, CD44 is the most often described biomarker. ${ }^{66}$ CD44 signaling is a highly orchestrated process. ${ }^{67}$ Shedding of the ectodomain of CD44 seems regulated through proteolysis by activated protease ADAM17, which was also detected in this study, and is activated by protein kinase $\mathrm{C}$ (PKC) and the small GTPAse Rac. This process enables migration of the cell. At the same time, the intracellular domain is released into the nucleus upon shedding and, there, regulates further gene transcription. $^{68}$ CD44 isoforms associate with glycoproteins tetraspanins and $\mathrm{N}$-cadherin (EpCAM), both identified in this study. CD44 and $\mathrm{N}$-cadherin are regulated by the $\beta$ catenin-dependent Wnt signaling pathway, a prominent target for cancer therapies. ${ }^{69,70}$

Cadherins are calcium-dependent adhesion molecules that mediate cell motility of cancer cells. Specifically, N-cadherins have been implicated in metastasis by enabling cancer cells to migrate through the endothelial layers into the bloodstream to reach their target organs. ${ }^{71}$ In contrast to cadherins, the immunoglobulin superfamily CAMs are cation-independent. Similar to cadherins, they play a key role in tumor cell invasion enabling dynamic cell-cell communication. ${ }^{72}$ Specifically, activated leukocyte-cell adhesion molecule ALCAM (CD 166) has been identified as cancer stem cell marker. ${ }^{63,73}$

CD 276 antigen is a ubiquitous surface protein that has previously been defined as a neuroblastoma biomarker. ${ }^{74}$ Interestingly, it was found that CD276 antigen may repress NK cell mediated lysis of the tumor cells. ${ }^{74}$ Thus, CD276 antigen may be an interesting therapeutic target where an effective reduction of the antigen's protective role of the tumor cells could increase antitumor efficacy of anticancer drugs.

Although not identified by the KEGG analysis, several other proteins are associated with cellular adhesion: mesothelin, ${ }^{75}$ which has previously been identified as a biomarker in cancer; the cell adhesion molecule neuroplastin (aka stromal cell derived receptor 1$) ;{ }^{76}$ podocalyxin, known to be implicated in adhesion, cell morphology and cancer progression; ${ }^{77}$ CD97 antigen, ${ }^{78,79}$ which has been associated with increased motility and invasiveness, that is the ability to break through endothelial cell barriers and attach to distant organs; galectin-3-binding protein, involved in integrin mediated cell adhesion and fibronectin matrix remodeling in tumor cells and basigin ${ }^{80,81}$ (an extracellular matrix metalloproteinase inducer EMMPRIN), which is known to be enriched on tumor cell surfaces. It stimulates collagenase and thus contributes to tumor progression. $^{82,83}$

\subsection{Focal Adhesion and Regulation of Actin Cytoskeleton}

Cell proliferation, survival, migration, and invasion are also regulated by focal adhesions, which are specialized complexes that anchor actin filaments to integrins. Integrins either bind to the RGD motif (laminin, fibronectin, and vitronectin) or the DGEA and GFOGER motifs (collagen). Downstream signaling including focal adhesion kinase enables reorganization of the actin cytoskeleton and thus allows cells to change their shape and migrate, a key process during metastasis.

In addition to the integrins and laminins, epidermal growth factor receptor (EGFR) was also identified in this study. EGFR has been implicated in focal adhesion, likely mediated through two members of the tensin family. ${ }^{84}$ Mutations leading to EGFR overexpression are involved in many cancers and are targets for a number of anticancer therapies. ${ }^{85}$ In cervical cancer, EGFR has also been suggested as a biomarker. ${ }^{86}$

\subsection{Lysosome}

Changes in lysosomal trafficking and increased expression of cathepsins are associated with tumor invasion and metastasis. Particularly, secreted cathepsins are involved in ECM degradation, which in turn enables tumor invasion. Lysosome-associated membrane glycoproteins LAMP1, 2, and 3 have been implicated in tumor progression and metastasis. ${ }^{87-89}$

The minor lysosomal membrane protein Niemann-Pick C1 was initially discovered to be involved in intracellular trafficking of cholesterol. More recent work also proposed a vesiclemediated pathway for lysosomal drug clearance. In contrast to drug-sensitive cell lines, multidrug resistant (MDR) cell lines were associated with loss of NPC1 activity and showed lysosomal drug accumulation. ${ }^{90}$ A mutation in the NiemannPick $\mathrm{C} 1$ protein may be the reason for the Niemann-Pick disease type $\mathrm{C} 1$ to develop but can also be acquired in MDR cancer cells. Interestingly, asparagine to serine mutations have been observed for both N961 and N968. ${ }^{51,52,91}$ Since serines cannot accept $\mathrm{N}$-glycosylations, this will likely alter the glycosylation pattern and thus the function of this protein. Monitoring glycosylation sites using the hydrazide capture method in combination with LC-MS/MS could therefore be a useful diagnostic tool for MDR development and, in a different context, Niemann-Pick disease type C1.

The multifunctional cation independent mannose-6-phosphate receptor (insulin growth factor 2 receptor, IGF2R, CD222) interacts with putative phospholipase B-like glycoprotein, both identified in this study, ${ }^{92}$ and binds to heparanase, which in turn cleaves heparan sulfate, thus essentially enabling ECM degradation. ${ }^{93}$ Together with Cathepsin D, IGF2R has been suggested as a biomarker ${ }^{94}$ and correlates with tumor progression. $^{95}$

\subsection{Pathways in Cancer}

In addition to the cancer-related proteins described above, KEGG analysis identified two additional glycoproteins as cancer-related: The facilitated glucose transporter (GLUT1)/ solute carrier family 2 , member 1 protein (SLC2A1), and HSP90B1; heat shock protein $90 \mathrm{kDa} \beta$. SLC2A1 is upregulated in radioresistant and chemoresitant hypoxic cells and has thus been suggested as a prognostic biomarker for cancer therapy. ${ }^{96}$

Owing to the stress that cells experience when they become cancerogenic, chaperones like the HSP90B1 have been identified as important drug targets. ${ }^{97}$ In addition, HSP90B1 was recently proposed as a prognostic biomarker for distant metastasis. $^{98}$

In addition to those proteins described above, some additional cancer biomarker are of note, e.g., CD 109 antigen, which is upregulated in squamous cell carcinomas, but not in adenocarcinoma and thus may serve as a diagnostic marker to differentiate these cancers; ${ }^{99}$ CD97 antigen, which was proposed as one of several biomarkers that are upregulated in 
invasive cervical carcinomas but not in normal cervical keratinocytes; ${ }^{100}$ antiviral defense protein CD317 (bone marrow stromal antigen 2 , tetherin), which inhibits viral release from cell surface; ${ }^{101}$ major and minor histocompatibility class proteins, which are proposed as diagnostic markers for cervical cancer; $^{102}$ cancer biomarker trophoblast glycoprotein; ${ }^{103}$ seizure 6-like protein, which has an increased expression in various lung cancers, but has not yet been investigated in cervical cancers, ${ }^{104}$ and inhibitor of $\mathrm{NF} \kappa \mathrm{B}$ kinase-interacting protein, which is a target of tumor suppressor $\mathrm{p} 53 .{ }^{105}$

\section{CONCLUSIONS}

In this study, the hydrazide capture method was used to enrich and profile $\mathrm{N}$-linked glycosylation sites in cytosolic and membrane-associated protein HeLa cells. We have demonstrated that the hydrazide method selectively enriches at least 100 -fold N-linked glycoproteins in contrast to unenriched samples. Additionally, the degree of unspecific interactions was determined to be very limited by comparison with nonoxidized samples which served as control. Hence, the enrichment of glycoproteins is due to an interaction with hydrazide and not due to any secondary interactions. By extending this methodology to the cytosolic fractions, we identified 268 unique glycosylation sites with an NXT/S motif, more than twice as many as previous studies. Both known and novel glycosylation sites were determined in a total of 106 glycoproteins. Many of these glycoproteins are cell surface proteins responsible for cell-cell or cell-matrix recognition, binding and migration. In addition, signaling cascades are activated by a number of enzymatic, mostly proteolytic processes. Cell adhesion, migration and proteolysis are highly associated with tumor invasiveness. In numerous studies, glycoproteins involved in these processes have been suggested to be either prognostic or diagnostic cancer biomarkers. We envision that this method could be applied in cancer tissue differential diagnostics and further developed to achieve best therapeutic outcomes in personalized medicine.

\section{ASSOCIATED CONTENT}

\section{Supporting Information}

Experimental procedures and supplementary figures, data tables, and spectra. This material is available free of charge via the Internet at http://pubs.acs.org.

\section{AUTHOR INFORMATION}

\section{Corresponding Author}

*Tel: 626-395-2339. E-mail: shess@caltech.edu.

Notes

The authors declare no competing financial interest.

\section{ACKNOWLEDGMENTS}

The Norwegian Research council (Project 197431/F20) (H.M.), the Faculty of Mathematics and Natural Sciences at the University of Oslo (H.M.), the Betty and Gordon Moore Foundation (R.L.J.G., M.S., S.H.), and the Beckman Institute (M.S., S.H.) are acknowledged for their financial support. We thank Ruth Huettenhain (ETHZ) for critical reading of the manuscript.

\section{REFERENCES}

(1) Masters, J. R. HeLa cells 50 years on: the good, the bad and the ugly. Nat. Rev. Cancer 2002, 2 (4), 315-319.

(2) Schwarz, E.; Freese, U. K.; Gissmann, L.; Mayer, W.; Roggenbuck, B.; Stremlau, A.; Hausen, H. z. Structure and transcription of human papillomavirus sequences in cervical carcinoma cells. Nature 1985, 314 (6006), 111-114.

(3) Lopez, J.; Poitevin, A.; Mendoza-Martinez, V.; Perez-Plasencia, C.; Garcia-Carranca, A. Cancer-initiating cells derived from established cervical cell lines exhibit stem-cell markers and increased radioresistance. BMC Cancer 2012, 12 (1), 48-62.

(4) Motté, P.; Takahashi, H.; Ozturk, M.; Wilson, B. E.; Wands, J. R Characterization of a Malignant Phenotype-associated Cell Surface Glycoprotein Common to Various Human Tumor Cells and Preferentially Expressed on Adenocarcinoma of the Lung. Cancer Res. 1989, 49 (6), 1349-1356.

(5) Li, C.; Zolotarevsky, E.; Thompson, I.; Anderson, M. A.; Simeone, D. M.; Casper, J. M.; Mullenix, M. C.; Lubman, D. M. A multiplexed bead assay for profiling glycosylation patterns on serum protein biomarkers of pancreatic cancer. Electrophoresis 2011, 32 (15), 2028-2035.

(6) Ressom, H. W.; Varghese, R. S.; Goldman, L.; An, Y.; Loffredo, C. A.; Abdel-Hamid, M.; Kyselova, Z.; Mechref, Y.; Novotny, M.; Drake, S. K.; Goldman, R. Analysis of MALDI-TOF Mass Spectrometry Data for Discovery of Peptide and Glycan Biomarkers of Hepatocellular Carcinoma. J. Proteome Res. 2008, 7 (2), 603-610.

(7) Varki, A.; Cummings, R.; Esko, J.; Freeze, H.; Hart, G.; Marth, J.Essentials of Glycobiology; Cold Spring Harbor Laboratory Press: Cold Spring Harbor, NY, 1999

(8) Schiess, R.; Wollscheid, B.; Aebersold, R. Targeted proteomic strategy for clinical biomarker discovery. Mol. Oncol. 2009, 3 (1), 3344.

(9) Lazar, I. M.; Lazar, A. C.; Cortes, D. F.; Kabulski, J. L. Recent advances in the MS analysis of glycoproteins: Theoretical considerations. Electrophoresis 2011, 32 (1), 3-13.

(10) Zhang, H.; Loriaux, P.; Eng, J.; Campbell, D.; Keller, A.; Moss, P.; Bonneau, R.; Zhang, N.; Zhou, Y.; Wollscheid, B.; Cooke, K.; Yi, E.; Lee, H.; Peskind, E.; Zhang, J.; Smith, R.; Aebersold, R. UniPep - a database for human $\mathrm{N}$-linked glycosites: a resource for biomarker discovery. Genome Biol. 2006, 7 (8), R73.

(11) Gonzalez-Begne, M.; Lu, B.; Liao, L.; Xu, T.; Bedi, G.; Melvin, J. E.; Yates, J. R. Characterization of the Human Submandibular/ Sublingual Saliva Glycoproteome Using Lectin Affinity Chromatography Coupled to Multidimensional Protein Identification Technology. J. Proteome Res. 2011, 10 (11), 5031-5046.

(12) Zhang, Y.; Giboulot, A.; Zivy, M.; Valot, B.; Jamet, E.; Albenne, C. Combining various strategies to increase the coverage of the plant cell wall glycoproteome. Phytochemistry 2011, 72 (10), 1109-1123.

(13) Zeng, Z.; Hincapie, M.; Pitteri, S. J.; Hanash, S.; Schalkwijk, J.; Hogan, J. M.; Wang, H.; Hancock, W. S. A Proteomics Platform Combining Depletion, Multi-lectin Affinity Chromatography (MLAC), and Isoelectric Focusing to Study the Breast Cancer Proteome. Anal. Chem. 2011, 83 (12), 4845-4854.

(14) Drake, P. M.; Schilling, B.; Niles, R. K.; Prakobphol, A.; Li, B.; Jung, K.; Cho, W.; Braten, M.; Inerowicz, H. D.; Williams, K.; Albertolle, M.; Held, J. M.; Iacovides, D.; Sorensen, D. J.; Griffith, O. L.; Johansen, E.; Zawadzka, A. M.; Cusack, M. P.; Allen, S.; Gormley, M.; Hall, S. C.; Witkowska, H. E.; Gray, J. W.; Regnier, F. E.; Gibson, B. W.; Fisher, S. J. A lectin chromatography/mass spectrometry discovery workflow identifies putative biomarkers of aggressive breast cancers. J. Proteome Res. 2012, 11 (4), 2508-2520.

(15) Liu, Y.; He, J.; Li, C.; Benitez, R.; Fu, S.; Marrero, J.; Lubman, D. M. Identification and Confirmation of Biomarkers Using an Integrated Platform for Quantitative Analysis of Glycoproteins and Their Glycosylations. J. Proteome Res. 2009, 9 (2), 798-805.

(16) Yang, F.; Lin, Z.; He, X.; Chen, L.; Zhang, Y. Synthesis and application of a macroporous boronate affinity monolithic column using a metal-organic gel as a porogenic template for the specific 
capture of glycoproteins. J. Chromatogr., A 2011, 1218 (51), 91949201.

(17) Ren, L.; Liu, Y.; Dong, M.; Liu, Z. Synthesis of hydrophilic boronate affinity monolithic capillary for specific capture of glycoproteins by capillary liquid chromatography. J. Chromatogr., A 2009, 1216 (47), 8421-8425.

(18) Lin, Z. A.; Pang, J. L.; Lin, Y.; Huang, H.; Cai, Z. W.; Zhang, L.; Chen, G. N., Preparation and evaluation of a phenylboronate affinity monolith for selective capture of glycoproteins by capillary liquid chromatography. Analyst 2011, 136, (16).

(19) Gilar, M.; Yu, Y.-Q.; Ahn, J.; Xie, H.; Han, H.; Ying, W.; Qian, $\mathrm{X}$. Characterization of glycoprotein digests with hydrophilic interaction chromatography and mass spectrometry. Anal. Biochem. 2011, 417 (1), 80-88.

(20) Yeh, C.-H.; Chen, S.-H.; Li, D.-T.; Lin, H.-P.; Huang, H.-J.; Chang, C.-I.; Shih, W.-L.; Chern, C.-L.; Shi, F.-K.; Hsu, J.-L. Magnetic bead-based hydrophilic interaction liquid chromatography for glycopeptide enrichments. J. Chromatogr., A 2012, 1224 (0), 70-78.

(21) Whelan, S. A.; Lu, M.; He, J.; Yan, W.; Saxton, R. E.; Faull, K. F.; Whitelegge, J. P.; Chang, H. R. Mass Spectrometry (LC-MS/MS) SiteMapping of N-Glycosylated Membrane Proteins for Breast Cancer Biomarkers. J. Proteome Res. 2009, 8 (8), 4151-4160.

(22) Zhou, Y.; Aebersold, R.; Zhang, H. Isolation of N-Linked Glycopeptides from Plasma. Anal. Chem. 2007, 79 (15), 5826-5837.

(23) Wollscheid, B.; Bausch-Fluck, D.; Henderson, C.; O’Brien, R.; Bibel, M.; Schiess, R.; Aebersold, R; Watts, J. D. Mass-spectrometric identification and relative quantification of $\mathrm{N}$-linked cell surface glycoproteins. Nat. Biotechnol. 2009, 27 (4), 378-386.

(24) Berven, F. S.; Ahmad, R.; Clauser, K. R.; Carr, S. A. Optimizing Performance of Glycopeptide Capture for Plasma Proteomics. J. Proteome Res. 2010, 9 (4), 1706-1715.

(25) Zhang, H.; Li, X.-j.; Martin, D. B.; Aebersold, R. Identification and quantification of $\mathrm{N}$-linked glycoproteins using hydrazide chemistry, stable isotope labeling and mass spectrometry. Nat. Biotechnol. 2003, 21 (6), 660-666.

(26) Kim, Y. J.; Zaidi-Ainouch, Z.; Gallien, S.; Domon, B. Mass spectrometry-based detection and quantification of plasma glycoproteins using selective reaction monitoring. Nat. Protocols 2012, 7 (5), 859-871.

(27) Hopf, P. S.; Ford, R. S.; Zebian, N.; Merkx-Jacques, A.; Vijayakumar, S.; Ratnayake, D.; Hayworth, J.; Creuzenet, C. Protein glycosylation in Helicobacter pylori: beyond the flagellins? PloS One 2011, 6 (9), e25722.

(28) Chen, Y.; Cao, J.; Yan, G.; Lu, H.; Yang, P. Two-step protease digestion and glycopeptide capture approach for accurate glycosite identification and glycoprotein sequence coverage improvement. Talanta 2011, 85 (1), 70-5.

(29) Wang, L.; Aryal, U. K.; Dai, Z.; Mason, A. C.; Monroe, M. E.; Tian, Z.-X.; Zhou, J.-Y.; Su, D.; Weitz, K. K.; Liu, T.; Camp, D. G.; Smith, R. D.; Baker, S. E.; Qian, W.-J. Mapping N-Linked Glycosylation Sites in the Secretome and Whole Cells of Aspergillus niger Using Hydrazide Chemistry and Mass Spectrometry. J. Proteome Res. 2012, 11, 143-156.

(30) Zhang, L.; Katselis, G. S.; Moore, R. E.; Lekpor, K.; Goto, R. M.; Lee, T. D.; Miller, M. M. Proteomic analysis of surface and endosomal membrane proteins from the avian LMH epithelial cell line. J. Proteome Res. 2011, 10 (9), 3973-82.

(31) Danzer, C.; Eckhardt, K.; Schmidt, A.; Fankhauser, N.; Ribrioux, S.; Wollscheid, B.; Müller, L.; Schiess, R.; Züllig, R; Lehmann, R.; Spinas, G.; Aebersold, R.; Krek, W. Comprehensive Description of the N-Glycoproteome of Mouse Pancreatic $\beta$-Cells and Human Islets. J. Proteome Res. 2011, 11 (3), 1598-1608.

(32) Ang, C. S.; Binos, S.; Knight, M. I.; Moate, P. J.; Cocks, B. G.; McDonagh, M. B. Global survey of the bovine salivary proteome: integrating multidimensional prefractionation, targeted, and glycocapture strategies. J. Proteome Res. 2011, 10 (11), 5059-69.

(33) Parker, B. L.; Palmisano, G.; Edwards, A. V.; White, M. Y.; Engholm-Keller, K.; Lee, A.; Scott, N. E.; Kolarich, D.; Hambly, B. D.; Packer, N. H.; Larsen, M. R.; Cordwell, S. J. Quantitative N-linked glycoproteomics of myocardial ischemia and reperfusion injury reveals early remodeling in the extracellular environment. Mol. Cell. Proteomics 2011, 10 (8), M110 006833.

(34) Madian, A. G.; Myracle, A. D.; Diaz-Maldonado, N.; Rochelle, N. S.; Janle, E. M.; Regnier, F. E. Determining the effects of antioxidants on oxidative stress induced carbonylation of proteins. Anal. Chem. 2011, 83 (24), 9328-36.

(35) Graham, R. L. J.; Kalli, A.; Smith, G. T.; Sweredoski, M. J.; Hess, S. Avoiding pitfalls in proteomics sample preparation. Biomacromol. Mass Spectrom. 2011, 2 (4), 273-284.

(36) Rappsilber, J.; Ishihama, Y.; Mann, M. Stop and Go Extraction Tips for Matrix-Assisted Laser Desorption/Ionization, Nanoelectrospray, and LC/MS Sample Pretreatment in Proteomics. Anal. Chem. 2002, 75 (3), 663-670.

(37) Cox, J.; Mann, M. MaxQuant enables high peptide identification rates, individualized p.p.b.-range mass accuracies and proteome-wide protein quantification. Nat. Biotechnol. 2008, 26 (12), 1367-1372.

(38) Crooks, G. E.; Hon, G.; Chandonia, J.-M.; Brenner, S. E. WebLogo: A Sequence Logo Generator. Genome Res. 2004, 14 (6), $1188-1190$.

(39) Keller, A.; Nesvizhskii, A. I.; Kolker, E.; Aebersold, R. Empirical Statistical Model To Estimate the Accuracy of Peptide Identifications Made by MS/MS and Database Search. Anal. Chem. 2002, 74 (20), $5383-5392$.

(40) Nesvizhskii, A. I.; Keller, A.; Kolker, E.; Aebersold, R. A Statistical Model for Identifying Proteins by Tandem Mass Spectrometry. Anal. Chem. 2003, 75 (17), 4646-4658.

(41) Consortium, T. U. Reorganizing the protein space at the Universal Protein Resource (UniProt). Nucleic Acids Res. 2012, 40 (D1), D71-D75.

(42) Cote, R.; Jones, P.; Martens, L.; Kerrien, S.; Reisinger, F.; Lin, Q.; Leinonen, R.; Apweiler, R.; Hermjakob, H. The Protein Identifier Cross-Referencing (PICR) service: reconciling protein identifiers across multiple source databases. BMC Bioinf. 2007, 8 (1), 401-415.

(43) Huang, D. W.; Sherman, B. T.; Lempicki, R. A. Systematic and integrative analysis of large gene lists using DAVID bioinformatics resources. Nat. Protocols 2008, 4 (1), 44-57.

(44) Tanabe, M.; Kanehisa, M., Using the KEGG Database Resource. In Current Protocols in Bioinformatics; John Wiley \& Sons, Inc.: New York, 2002.

(45) McDonald, C. A.; Yang, J. Y.; Marathe, V.; Yen, T. Y.; Macher, B. A. Combining results from lectin affinity chromatography and glycocapture approaches substantially improves the coverage of the glycoproteome. Mol. Cell. Proteomics 2009, 8 (2), 287-301.

(46) Yan, B.; Zhang, W.; Ding, J.; Gao, P. Sequence Pattern for the Occurrence of N-Glycosylation in Proteins. J. Protein Chem. 1999, 18 (5), 511-521.

(47) Chen, R.; Jiang, X.; Sun, D.; Han, G.; Wang, F.; Ye, M.; Wang, L.; Zou, H. Glycoproteomics Analysis of Human Liver Tissue by Combination of Multiple Enzyme Digestion and Hydrazide Chemistry. J. Proteome Res. 2009, 8 (2), 651-661.

(48) Onda, M.; Nagata, S.; Ho, M.; Bera, T. K.; Hassan, R.; Alexander, R. H.; Pastan, I. Megakaryocyte Potentiation Factor Cleaved from Mesothelin Precursor Is a Useful Tumor Marker in the Serum of Patients with Mesothelioma. Clin. Cancer Res. 2006, 12 (14), 4225-4231.

(49) Feng, Y.; Xiao, X.; Zhu, Z.; Streaker, E.; Ho, M.; Pastan, I.; Dimitrov, D. S. A novel human monoclonal antibody that binds with high affinity to mesothelin-expressing cells and kills them by antibodydependent cell-mediated cytotoxicity. Mol. Cancer Ther. 2009, 8 (5), $1113-1118$.

(50) Ho, M.; Onda, M.; Wang, Q.-c.; Hassan, R.; Pastan, I.; Lively, M. O. Mesothelin Is Shed from Tumor Cells. Cancer Epidemiol. Biomarkers Prev. 2006, 15 (9), 1751.

(51) Millat, G.; Baïlo, N.; Molinero, S.; Rodriguez, C.; Chikh, K.; Vanier, M. T. Niemann-Pick $C$ disease: Use of denaturing high performance liquid chromatography for the detection of NPC1 and NPC2 genetic variations and impact on management of patients and families. Mol. Genet. Metab. 2005, 86 (1-2), 220-232. 
(52) Yang, C. C.; Su, Y. N.; Chiou, P. C.; Fietz, M. J.; Yu, C. L.; Hwu, W. L.; Lee, M. J. Six novel NPC1 mutations in Chinese patients with Niemann-Pick disease type C. J. Neurol. Neurosurg. Psychiatry 2005, 76 (4), 592-5.

(53) Palmisano, G.; Melo-Braga, M. N.; Engholm-Keller, K.; Parker, B. L.; Larsen, M. R. Chemical Deamidation: A Common Pitfall in Large-Scale N-Linked Glycoproteomic Mass Spectrometry-Based Analyses. J. Proteome Res. 2012, 11 (3), 1949-1957.

(54) Parker, B. L.; Palmisano, G.; Edwards, A. V. G.; White, M. Y.; Engholm-Keller, K.; Lee, A.; Scott, N. E.; Kolarich, D.; Hambly, B. D.; Packer, N. H.; Larsen, M. R.; Cordwell, S. J., Quantitative N-linked Glycoproteomics of Myocardial Ischemia and Reperfusion Injury Reveals Early Remodeling in the Extracellular Environment. Mol. Cell. Proteomics 2011, 10, (8).

(55) Küster, B.; Mann, M. 18O-Labeling of N-Glycosylation Sites To Improve the Identification of Gel-Separated Glycoproteins Using Peptide Mass Mapping and Database Searching. Anal. Chem. 1999, 71 (7), 1431-1440.

(56) Eisenhaber, B.; Bork, P.; Eisenhaber, F. Prediction of Potential GPI-modification Sites in Proprotein Sequences. J. Mol. Biol. 1999, 292 (3), 741-758.

(57) Luo, W.-R.; Wu, A.-B.; Fang, W.-Y.; Li, S.-Y.; Yao, K.-T. Nuclear expression of $\mathrm{N}$-cadherin correlates with poor prognosis of nasopharyngeal carcinoma. Histopathology 2012, DOI: 10.1111/ j.1365-2559.2012.04212.x.

(58) Giebultowicz, J.; Polanska-Plachta, M.; Wroczynski, P.; Zaborowski, P.; Polanski, J. How echinoccocosis affects potential cancer markers in plasma: galectin-3, sN-cadherin and sE-cadherin? a preliminary report. Diagn. Pathol. 2012, 7 (1), 17.

(59) Defilles, C.; Montero, M.-P.; Lissitzky, J.-C.; Rome, S.; Siret, C.; Luis, J.; André, F.; Rigot, V. $\alpha$ v integrin processing interferes with the cross-talk between $\alpha v \beta 5 / \beta 6$ and $\alpha 2 \beta 1$ integrins. Biol. Cell 2011, 103 (11), 519-529.

(60) Ramirez, N. E.; Zhang, Z.; Madamanchi, A.; Boyd, K. L.; O’Rear, L. D.; Nashabi, A.; Li, Z.; Dupont, W. D.; Zijlstra, A.; Zutter, M. M. The $\alpha 2 \beta 1$ integrin is a metastasis suppressor in mouse models and human cancer. J. Clin. Invest. 2011, 121 (1), 226-237.

(61) Dingemans, A.-M.; van den Boogaart, V.; Vosse, B.; van Suylen, R.-J.; Griffioen, A.; Thijssen, V. Integrin expression profiling identifies integrin alpha5 and beta1 as prognostic factors in early stage non-small cell lung cancer. Mol. Cancer 2010, 9 (1), 152.

(62) Saalbach, A.; Wetzel, A.; Haustein, U.-F.; Sticherling, M.; Simon, J. C.; Anderegg, U. Interaction of human Thy-1 (CD 90) with the integrin [alpha]v[beta]3 (CD51//CD61): an important mechanism mediating melanoma cell adhesion to activated endothelium. Oncogene 2005, 24 (29), 4710-4720.

(63) Weidle, U. H.; Eggle, D.; Klostermann, S.; Swart, G. W. M. ALCAM/CD166: Cancer-related Issues. Cancer Genomics Proteomics 2010, 7 (5), 231-243.

(64) Yoon, C.-S.; Kim, K.-D.; Park, S.-N.; Cheong, S.-W. $\alpha 6$ Integrin Is the Main Receptor of Human Papillomavirus Type 16 VLP. Biochem. Biophys. Res. Commun. 2001, 283 (3), 668-673.

(65) Shafti-Keramat, S.; Handisurya, A.; Kriehuber, E.; Meneguzzi, G.; Slupetzky, K.; Kirnbauer, R. Different Heparan Sulfate Proteoglycans Serve as Cellular Receptors for Human Papillomaviruses. J. Virol. Methods 2003, 77 (24), 13125-13135.

(66) Lobo, N. A.; Shimono, Y.; Qian, D.; Clarke, M. F. The Biology of Cancer Stem Cells. Annu. Rev. Cell Dev. Biol. 2007, 23 (1), 675699.

(67) Ponta, H.; Sherman, L.; Herrlich, P. A. CD44: From adhesion molecules to signalling regulators. Nat. Rev. Mol. Cell. Biol. 2003, 4 (1), $33-45$.

(68) Nagano, O.; Saya, H. Mechanism and biological significance of CD44 cleavage. Cancer Sci. 2004, 95 (12), 930-935.

(69) Wielenga, V. J. M.; Smits, R.; Korinek, V.; Smit, L.; Kielman, M.; Fodde, R.; Clevers, H.; Pals, S. T. Expression of CD44 in Apc and TcfMutant Mice Implies Regulation by the WNT Pathway. Am. J. Pathol. 1999, 154 (2), 515-523.
(70) Hue, H. L.; Ruiwen, Z.; Rex, C. H.; Elizabeth, R.; Quan, K.; Weike, S.; Jong, K. P.; Hui, W.; Ying, P.; Wei, J.; Tong, C. h. u. a. n. H., Wnt/beta-Catenin Signaling Pathway as Novel Cancer Drug Targets. Curr. Cancer Drug Tar. 2004, 4 (8), 653-671.

(71) Ignacio, R.-C.; Mark, A. J. C.; Alexander, R. A. A.; Dirk, D. Multi-scale modelling of cancer cell intravasation: the role of cadherins in metastasis. Phys. Biol. 2009, 6 (1), 016008.

(72) Sloan, K.; Eustace, B.; Stewart, J.; Zehetmeier, C.; Torella, C.; Simeone, M.; Roy, J.; Unger, C.; Louis, D.; Ilag, L.; Jay, D. CD155/ PVR plays a key role in cell motility during tumor cell invasion and migration. BMC Cancer 2004, 4 (1), 73.

(73) Rosso, O.; Piazza, T.; Bongarzone, I.; Rossello, A.; Mezzanzanica, D.; Canevari, S.; Orengo, A. M.; Puppo, A.; Ferrini, S.; Fabbi, M. The ALCAM Shedding by the Metalloprotease ADAM17/TACE Is Involved in Motility of Ovarian Carcinoma Cells. Mol. Cancer Res. 2007, 5 (12), 1246-1253.

(74) Castriconi, R.; Dondero, A.; Augugliaro, R.; Cantoni, C.; Carnemolla, B.; Sementa, A. R.; Negri, F.; Conte, R.; Corrias, M. V.; Moretta, L.; Moretta, A.; Bottino, C. Identification of 4Ig-B7-H3 as a neuroblastoma-associated molecule that exerts a protective role from an NK cell-mediated lysis. Proc. Natl. Acad. Sci. U.S.A. 2004, 101 (34), 12640-12645.

(75) Rump, A.; Morikawa, Y.; Tanaka, M.; Minami, S.; Umesaki, N.; Takeuchi, M.; Miyajima, A. Binding of Ovarian Cancer Antigen CA125/MUC16 to Mesothelin Mediates Cell Adhesion. J. Biol. Chem. 2004, 279 (10), 9190-9198.

(76) Sanz-Rodríguez, F.; Hidalgo, A.; Teixidó, J. Chemokine stromal cell-derived factor- $1 \alpha$ modulates VLA- 4 integrin-mediated multiple myeloma cell adhesion to CS-1/fibronectin and VCAM-1. Blood 2001, 97 (2), 346-351.

(77) Nielsen, J. S.; McNagny, K. M. The Role of Podocalyxin in Health and Disease. J. Am. Soc. Nephrol. 2009, 20 (8), 1669-1676.

(78) Liu, D.; Trajanowicz, B.; Radestock, Y.; Fu, T.; Hammje, K.; Chen, L.; Hoang-Vu, C. Role of CD97 isoforms in gastric carcinoma. Int. J. Oncol. 2010, 36 (6), 1401-1408.

(79) Galle, J.; Sittig, D.; Hanisch, I.; Wobus, M.; Wandel, E.; Loeffler, M.; Aust, G. Individual Cell-Based Models of Tumor-Environment Interactions: Multiple Effects of CD97 on Tumor Invasion. Am. J. Pathol. 2006, 169 (5), 1802-1811.

(80) Sasaki, T.; Brakebusch, C.; Engel, J.; Timpl, R. Mac-2 binding protein is a cell-adhesive protein of the extracellular matrix which selfassembles into ring-like structures and binds [beta] 1 integrins, collagens and fibronectin. EMBO J. 1998, 17 (6), 1606-1613.

(81) Lagana, A.; Goetz, J. G.; Cheung, P.; Raz, A.; Dennis, J. W.; Nabi, I. R. Galectin Binding to Mgat5-Modified N-Glycans Regulates Fibronectin Matrix Remodeling in Tumor Cells. Mol. Cell. Biol. 2006, 26 (8), 3181-3193.

(82) Biswas, C.; Zhang, Y.; DeCastro, R.; Guo, H.; Nakamura, T.; Kataoka, H.; Nabeshima, K. The Human Tumor Cell-derived Collagenase Stimulatory Factor (Renamed EMMPRIN) Is a Member of the Immunoglobulin Superfamily. Cancer Res. 1995, 55 (2), 434439.

(83) Guo, H.; Majmudar, G.; Jensen, T. C.; Biswas, C.; Toole, B. P.; Gordon, M. K. Characterization of the gene for human EMMPRIN, a tumor cell surface inducer of matrix metalloproteinases. Gene 1998, $220(1-2), 99-108$.

(84) Katz, M.; Amit, I.; Citri, A.; Shay, T.; Carvalho, S.; Lavi, S.; Milanezi, F.; Lyass, L.; Amariglio, N.; Jacob-Hirsch, J.; Ben-Chetrit, N.; Tarcic, G.; Lindzen, M.; Avraham, R.; Liao, Y.-C.; Trusk, P.; Lyass, A.; Rechavi, G.; Spector, N. L.; Lo, S. H.; Schmitt, F.; Bacus, S. S.; Yarden, Y. A reciprocal tensin-3-cten switch mediates EGF-driven mammary cell migration. Nat. Cell Biol. 2007, 9 (8), 961-969.

(85) Seshacharyulu, P.; Ponnusamy, M. P.; Haridas, D.; Jain, M.; Ganti, A. K.; Batra, S. K. Targeting the EGFR signaling pathway in cancer therapy. Expert Opin. Ther. Targets 2012, 16 (1), 15-31.

(86) Soonthornthum, T.; Arias-Pulido, H.; Joste, N.; Lomo, L.; Muller, C.; Rutledge, T.; Verschraegen, C. Epidermal growth factor receptor as a biomarker for cervical cancer. Ann. Oncol. 2011, 22, $2166-2178$ 
(87) Krishnan, V.; Bane, S. M.; Kawle, P. D.; Naresh, K. N.; Kalraiya, R. D. Altered melanoma cell surface glycosylation mediates organ specific adhesion and metastasis via lectin receptors on the lung vascular endothelium. Clin. Exp. Metastasis 2005, 22 (1), 11-24.

(88) Tung, J.-N. T., T-Y; Tai, C-J; Yeh, K-T; Cheng, Y-W; Jiang, MC Distribution of Lysosome-associated Membrane Proteins-1 and -2, and Cathepsin D in Eosinophilic Granular Bodies: Possible Relationship to Cyst Development in Pilocytic Astrocytomas. J. Int. Med. Res. 2010, 38 (4), 1354-1364.

(89) Nagelkerke, A.; Mujcic, H.; Bussink, J.; Wouters, B. G.; van Laarhoven, H. W. M.; Sweep, F. C. G. J.; Span, P. N. Hypoxic regulation and prognostic value of LAMP3 expression in breast cancer. Cancer 2011, 117 (16), 3670-3681.

(90) Gong, Y.; Duvvuri, M.; Duncan, M. B.; Liu, J.; Krise, J. P. Niemann-Pick C1 Protein Facilitates the Efflux of the Anticancer Drug Daunorubicin from Cells According to a Novel Vesicle-Mediated Pathway. J. Pharmacol. Exp. Ther. 2006, 316 (1), 242-247.

(91) Dvorakova, L.; Sikora, J.; Hrebicek, M.; Hulkova, H.; Bouckova, M.; Stolnaja, L.; Elleder, M. Subclinical course of adult visceral Niemann-Pick type $\mathrm{C} 1$ disease. A rare or underdiagnosed disorder? J. Inherit. Metab. Dis. 2006, 29 (4), 591-591.

(92) Jensen, A. G.; Chemali, M.; Chapel, A.; Kieffer-Jaquinod, S.; Jadot, M.; Garin, J.; Journet, A. Biochemical characterization and lysosomal localization of the mannose-6-phosphate protein p76 (hypothetical protein LOC196463). Biochem. J. 2007, 402, 449-458.

(93) Wood, R. J.; Hulett, M. D. Cell Surface-expressed Cationindependent Mannose 6-Phosphate Receptor (CD222) Binds Enzymatically Active Heparanase Independently of Mannose 6Phosphate to Promote Extracellular Matrix Degradation. J. Biol. Chem. 2008, 283 (7), 4165-4176.

(94) Zhao, Y.; Escot, C.; Maudelonde, T.; Puech, C.; Rouanet, P.; Rochefort, H. Correlation between Mannose-6-phosphate/IGFII Receptor and Cathepsin D RNA Levels by in Situ Hybridization in Benign and Malignant Mammary Tumors. Cancer Res. 1993, 53 (12), 2901-2905.

(95) Rasmussen, A. A.; Cullen, K. J. Paracrine/autocrine regulation of breast cancer by the insulin-like growth factors. Breast Cancer Res. Tr. 1998, 47 (3), 219-233.

(96) Airley, R. E.; Loncaster, J.; Raleigh, J. A.; Harris, A. L.; Davidson, S. E.; Hunter, R. D.; West, C. M. L.; Stratford, I. J. GLUT-1 and CAIX as intrinsic markers of hypoxia in carcinoma of the cervix: Relationship to Pimonidazole binding. Int. J. Cancer 2003, 104 (1), 85-91.

(97) Nahleh, Z.; Tfayli, A.; Najm, A.; El Sayed, A.; Nahle, Z. Heat shock proteins in cancer: targeting the 'chaperones'. Future Med. Chem. 2012, 4 (7), 927-935.

(98) Cawthorn, T. R.; Moreno, J. C.; Dharsee, M.; Tran-Thanh, D.; Ackloo, S.; Zhu, P. H.; Sardana, G.; Chen, J.; Kupchak, P.; Jacks, L. M.; Miller, N. A.; Youngson, B. J.; Iakovlev, V.; Guidos, C. J.; Vallis, K. A.; Evans, K. R.; McCready, D.; Leong, W. L.; Done, S. J. Proteomic Analyses Reveal High Expression of Decorin and Endoplasmin (HSP90B1) Are Associated with Breast Cancer Metastasis and Decreased Survival. PloS One 2012, 7 (2), e30992.

(99) Hashimoto, M.; Ichihara, M.; Watanabe, T.; Kawai, K.; Koshikawa, K.; Yuasa, N.; Takahashi, T.; Yatabe, Y.; Murakumo, Y.; Zhang, J.-m.; Nimura, Y.; Takahashi, M. Expression of CD109 in human cancer. Oncogene 2004, 23 (20), 3716-3720.

(100) Santin, A. D.; Zhan, F.; Bignotti, E.; Siegel, E. R.; Cané, S.; Bellone, S.; Palmieri, M.; Anfossi, S.; Thomas, M.; Burnett, A.; Kay, H. H.; Roman, J. J.; O’Brien, T. J.; Tian, E.; Cannon, M. J.; Shaughnessy, J., Jr.; Pecorelli, S. Gene expression profiles of primary HPV16- and HPV18-infected early stage cervical cancers and normal cervical epithelium: identification of novel candidate molecular markers for cervical cancer diagnosis and therapy. Virology 2005, 331 (2), 269291.

(101) Yang, H.; Wang, J.; Jia, X.; McNatt, M. W.; Zang, T.; Pan, B.; Meng, W.; Wang, H.-W.; Bieniasz, P. D.; Xiong, Y. Structural insight into the mechanisms of enveloped virus tethering by tetherin. Proc. Natl. Acad. Sci. U.S.A. 2010, 107, 18428-18432.
(102) del Toro-Arreola, S.; Arreygue-Garcia, N.; Aguilar-Lemarroy, A.; Cid-Arregui, A.; Jimenez-Perez, M.; Haramati, J.; Barros-Nunez, P.; Gonzalez-Ramella, O.; del Toro-Arreola, A.; Ortiz-Lazareno, P.; Hernandez-Flores, G.; Bravo-Cuellar, A.; Daneri-Navarro, A.; JaveSuarez, L. MHC class I-related chain A and B ligands are differentially expressed in human cervical cancer cell lines. Cancer Cell Int. 2011, 11 (1), 15 .

(103) Varughese, J.; Cocco, E.; Bellone, S.; Ratner, E.; Silasi, D.-A.; Azodi, M.; Schwartz, P. E.; Rutherford, T. J.; Buza, N.; Pecorelli, S.; Santin, A. D. Cervical carcinomas overexpress human trophoblast cellsurface marker (Trop-2) and are highly sensitive to immunotherapy with hRS7, a humanized monoclonal anti-Trop-2 antibody. Am. J. Obstet. Gynecol. 2011, 205 (6), 567.e1-567.e7.

(104) Gorlov, I. P.; Meyer, P.; Liloglou, T.; Myles, J.; Boettger, M. B.; Cassidy, A.; Girard, L.; Minna, J. D.; Fischer, R.; Duffy, S.; Spitz, M. R.; Haeussinger, K.; Kammerer, S.; Cantor, C.; Dierkesmann, R.; Field, J. K.; Amos, C. I. Seizure 6-Like (SEZ6L) Gene and Risk for Lung Cancer. Cancer Res. 2007, 67 (17), 8406-8411.

(105) Hofer-Warbinek, R.; Schmid, J. A.; Mayer, H.; Winsauer, G.; Orel, L.; Mueller, B.; Wiesner, C.; Binder, B. R.; de Martin, R. A highly conserved proapoptotic gene, IKIP, located next to the APAF1 gene locus, is regulated by p53. Cell Death Differ. 2004, 11 (12), 13171325. 